\title{
Why should we save the wild relatives of domesticated animals?
}

\author{
Kent H. Redford and Nigel Duder
}

In his opus on the pheasants of the world, published in the early 1900s, the zoologist William Beebe wrote that his observations on wild red jungle fowl, the progenitor of domestic chickens, in the jungles of Asia, suggested 'an infusion of the blood of native village birds' into the genome of these wild relatives (Beebe, 1918-1922, in Lawler, 2014). Roll forward almost a century and in 2014, Lawler reported in his wonderful book on the history of chickens that most if not all red jungle fowl have incorporated genes from domestic chickens (Lawler, 2014). Yet the IUCN Red List categorizes the red jungle fowl, Gallus gallus as being of Least Concern because of its large range and sizeable population (IUCN, 2018).

All domesticated animals originated from wild ancestors. Many of these wild ancestors-such as the wild ass, the ancestor of the donkey-are in danger of extinction. Some are already extinct, as with the wild relative of the dromedaries, gone 2,00o years ago. Others are in danger of being hollowed out genetically, as with chickens. The danger of extinction through genetic swamping from domestic breeds is poorly documented but appears to be occurring with wild yaks, Bactrian camels, jungle fowl, and perhaps other species. This should not be a surprise as modern genomic studies have concluded that the domestication process involved thousands of years of interbreeding between domestic stock and their wild relatives-partially to avoid the need for herders to maintain males, partially because of poor husbandry, and partially to continue to maintain desirable traits common in the wild species (Almathen et al., 2016).

The global community has long recognized the importance of conserving the wild relatives of domesticated plants. International organizations conserve crop germplasm, programmes work with traditional crop breeders to conserve landraces and traditional cropping practices, protected areas have been established to conserve crop wild relatives, and international treaties and agreements help achieve all of these activities, particularly under the auspices of the Food and Agricultural Organization (FAO) of the UN.

So if there are compelling reasons for saving the wild relatives of domestic plants, what about the wild relatives of

Kent H. RedFord Archipelago Consulting, 198 Danforth Street, Portland, Maine 04102, USA, Department of Environmental Studies, University of New England, Biddeford, Maine, USA, and Environmental Futures Research Institute, Griffith University, Queensland, Australia. E-mail redfordkh@gmail.com

Nigel Dudley Equilibrium, Bristol, UK, and School of Earth and Environmental Sciences, University of Queensland, Brisbane, Australia domestic animals? Unlike the case for crops, here the attention has focused almost exclusively on domestic breeds: Florida Cracker cattle, Ossabaw Island pigs, Black Welsh Mountain sheep, La Fleche chickens, and many others. Committees report, NGOs fundraise, herders are studied and incentivized, and global treaties create enabling conditions. All for breeds of already domesticated animals, which are in real danger of disappearing, but not for the wild relatives themselves.

The global community appears to be largely blind to the plight of vitally important species such as banteng, guar, wild yak, guanaco, wild ass, Mexican subspecies of wild turkeys, wild pigs and wild Bactrian camels. Furthermore, species vital in laboratory experiments are also disappearing, such as the axolotl (Vance, 2017), categorized by IUCN as Critically Endangered in the wild.

To our knowledge there has been no systematic investigation of the distribution and status of wild relatives of domesticated animals. A short 2010 article suggested that the conservation status of these species was considerably worse than that of most other mammals and birds (McGowan, 2010), but this assessment was based on the IUCN Red List, which does not consider the genetic integrity of a species. As this may be a major threat for some livestock relatives their conservation status may be even worse than hitherto assumed.

In 2015 FAO's Commission on Genetic Resources for Food and Agriculture issued a report on the state of the world's animal genetic resources (Scherf \& Pilling, 2015). Wild relatives receive next to no attention but the report's logic for domestic breeds is equally compelling for wild relatives: 'Livestock production systems face many challenges. The precise demands that will be placed on the livestock of the future are difficult to predict. However, coping with climate change, new disease challenges, restrictions on the availability of natural resources and changing market demands will require a diverse range of AnGR [animal genetic resources for food and agriculture]'.

In 2016 the Committee on World Food Security endorsed (ILRI, 2016) recommendations on roles for livestock in sustainable agricultural development for food security and nutrition (HLPE, 2016). Yet the focus was on domestic breeds.

The international community is starting to take notice, however. There is reference made to wild relatives in Aichi Biodiversity Target 13 of the Convention on Biological Diversity (CBD, 2018): 'By 2020, the genetic diversity of cultivated plants and farmed and domesticated animals and of 
wild relatives, including other socio-economically as well as culturally valuable species, is maintained, and strategies have been developed and implemented for minimizing genetic erosion and safeguarding their genetic diversity'. The same reference is found in the Sustainable Development Goals (UN, 2018): 'Goal 2. End hunger, achieve food security and improved nutrition and promote sustainable agriculture...2.5 By 2020 maintain the genetic diversity of seeds, cultivated plants and farmed and domesticated animals and their related wild species...' (our emphasis).

Many but not all of the policies aimed at crop wild relatives could be adapted for what could collectively become known as livestock wild relatives. For example, FAO has laid out a framework for integrating genetic diversity into national climate change adaptation planning (FAO, 2015) and this could serve for animals as well as plants. The model is clearly present in numerous recent pieces setting global conservation priorities for crop wild relatives (e.g. Castañeda-Álvarez et al., 2016). These treatments include consideration of how climate change will affect their conservation.

However, whereas conservation strategies for crop wild relatives can rely on a mixture of gene banks and the maintenance of live plants in protected areas or similar, for livestock the emphasis will necessarily be on maintaining healthy breeding populations, either captive or, preferably, in the wild. Protected areas can play a critical role (Rosenthal, 2010), as is the case for crop wild relatives. The need to prevent domestic crossbreeding may require either different management within protected areas or perhaps maintenance of captive breeding stock. Experience with reintroduction of Przewalski's horse into the wild, clawed back from a global population of just 13 individuals, shows that conservation strategies work (Xia et al., 2014).

So what should be done? We have identified a serious omission in conservation practice and global food security strategies. A focused programme of work is needed to fill current knowledge gaps and propose effective responses. This should start with an analysis of the conservation status (demographic, ecological and genetic) of key wild relatives of domesticated animals. Much of this information exists within the conservation community but has not been viewed through this particular lens. The assessments need to consider the extent to which current protected areas are adequately conserving the species, and whether management policies address both survival and risks of genetic swamping from domesticated breeds. Analysis of crop wild relatives found that they were disproportionately absent from global protected area systems (Stolton et al., 2008). Furthermore, an analysis of existing policy instruments is needed to determine if more explicit livestock wild relative policies are required. Together, such work will provide an overview of status, conservation options and gaps in both protected areas and their management approaches, along with policy recommendations to the agricultural and conservation communities. With this information, there will be a realistic chance of addressing this critical but so far undervalued ecosystem service.

\section{References}

Almathen, F., Charruau, P., Mohandesan, E., Mwacharo, J.M., Orozco-terWengel, P., Pitt, D. et al. (2016) Ancient and modern DNA reveal dynamics of domestication and crosscontinental dispersal of the dromedary. Proceedings of the National Academy of Sciences of the United States of America, 113, 6707-6712.

Beebe, W. (1918-1922) A Monograph of the Pheasants. Wiherby, London, UK

BirdLife International (2016) Gallus gallus. In The IUCN Red List of Threatened Species. Http://www.iucnredlist.org/details/22679199/ o. [accessed 5 February 2018].

Castañeda-Álvarez, N.P., Khoury, C.K., Achicanoy, H.A., Bernau, V., Dempewolf, H., Eastwood, R.J. et al. (2016) Global conservation priorities for crop wild relatives. Nature Plants, 2, doi. org/10.1038/NPLANTS.2016.22.

CBD (2018) Convention on Biological Diversity. Https://www.cbd.int/ [accessed 26 April 2018].

FaO (Food and Agriculture Organization) (2015) Voluntary Guidelines to Support the Integration of Genetic Diversity into National Climate Change Adaptation Planning. Commission on Genetic Resources for Food and Agriculture, Food and Agriculture Organization of The United Nations Rome, Italy.

HLPE (High Level Panel of Experts) (2016) Sustainable agricultural development for food security and nutrition: what roles for livestock? A report by the High Level Panel of Experts on Food Security and Nutrition of the Committee on World Food Security, Rome, Italy.

ILRI (Internatinal Livestock Research Institute) (2016) Livestock for food security and nutrition-Committee on World Food Security policy recommendations. Https://news.ilri.org/2017/ 05/10/livestock-for-food-security-and-nutrition-committee-onworld-food-security-policy-recommendations [accessed 5 February 2018].

LAWLER, A. (2014) Why did the chicken cross the world? Atria Paperbacks, New York, USA.

McGowan, P.J.K. (2010) Conservation status of wild relatives of animals used for food. Animal Genetic Resources, 47, 115-118.

Rosenthal, J.S. (2010) A review of the role of protected areas in conserving global domestic animal diversity. Animal Genetic Resources, 47, 101-113.

Scherf, B.D. \& Pilling, D. (eds) (2015) The Second Report on the State of the World's Animal Genetic Resources for Food and Agriculture. Commission on Genetic Resources for Food and Agriculture, Food and Agriculture Organization of The United Nations, Rome, Italy. Http://www.fao.org/publications/sowangr [accessed 26 April 2028].

Stolton, S., Boucher, T., Dudley, N., Hoekstra, J., Maxted, N. \& KeLL, S. (2008) Ecoregions with crop wild relatives are less well protected. Biodiversity, 9, 19-22.

UN (2018) Sustainable Development Goals. Htttps://sustainable development.un.org [accessed 26 April 2018].

VAnCE, E. (2017) The axolotl paradox. Nature, 551, 286-289.

Xia, C., CAO, J., Zhang, H., GaO, X., YAnG, W. \& Blank, D. (2014) Reintroduction of Przewalski's horse (Equus ferus przewalski) in Xinjiang, China: the status and experience. Biological Conservation, 177, 142-147. 